\section{An Effect of R-value (NCO/OH Molar Ratio) on Sealing Properties of Polyurethane Gaskets}

森賀 俊典 $1,2 *$. 青山 直揮 ${ }^{3} \cdot$ 田中 敬二 1

Toshinori MORIGA ${ }^{1,2^{*}}$, Naoki AOYAMA ${ }^{3}$ and Keiji TANAKA ${ }^{1}{ }^{1}$ Department of Applied Chemistry, Kyushu University, 744 Motooka, Fukuoka 819-0395, Japan, ${ }^{2}$ R\&D Center, Toyo Kohan Co., Ltd., 1296-1 Higashitoyoi, Kudamatsu, Yamaguchi 744-8611, Japan, ${ }^{3}$ Toyo Seikan Group Holdings, Ltd., 2-18-1 Higashigotanda, Shinagawa-ku, Tokyo 141-8627, Japan)*moriga.toshinori@toyokohan.co.jp

Poly (vinyl chloride)(PVC) has been often used to prepare plastisols that are widely utilized in sealing gaskets for wide-mouth glass jars. However, since there have been safety concerns surrounding these materials, safer alternative materials such as polyurethanes are considered. By varying the NCO/OH molar ratio, here referred to as the R-value, the sealing properties of the urethane gaskets prepared from an aliphatic diisocyanate adduct, polyols and various additives were investigated. The optimum range of the $\mathrm{R}$-values was found to be from 1.00 to 1.15 based on the desired mechanical properties of the prepared materials as effective sealing gaskets. Any value beyond this range means an excess amount of NCO groups resulting in an increased crosslinking as well as producing unreacted NCO groups behaving as dangling points, both of these yield unfavorable mechanical properties for the gaskets.

(Received on January 6, 2015)

(Accepted on May 7, 2015)

Key Words : Polyurethane, Sealing Gaskets, Closure, R-value, Mechanical Properties, Migration

\section{1. 緒言}

瓶詰め食品の密封に用いられる金属製キャップ (ツイス トオフキャップ，スクリューキャップ等）では，特に広口 ガラス瓶において, シーリング材としてPVCプラスチゾル が広く用いられてきた. 塩ビシーリング材は可塑剂の食品 への移行等, 多くの問題を抱え ${ }^{1-4)}$, 食品用途に限らず代 替材料の開発 ${ }^{5)}$ が望まれてきた.筆者らは代替材料としてウ レタンポリマーとウレタン・シーリング材を開発した ${ }^{6,7)}$. 既報では，開発した代表的なウレタンポリマーと添加剤か らなるウレタン・シーリング材の力学特性（動的粘弾性, 圧縮永久ひずみ，硬度）ならびにそれらをキャップに適用 した場合の性能について論じた ${ }^{8)}$ 。また，相反する特性の 密封性と開栓性が両立できたことを報告するとともに, 添 加剂である夕ルクと滑剤の凝集物が反応過程において溶融, 表面濃縮する, 滑り性発現の新たなメカニズムを提案した ${ }^{8)}$.

$\mathrm{NCO}$ 基と $\mathrm{OH}$ 基の反応からなるポリウレタンは，一般
に, $\mathrm{NCO}$ 基と $\mathrm{OH}$ 基を当量で配合し, 過不足なく反応さ せる. $\mathrm{R}$ 值（ $\mathrm{NCO}$ 基/ $\mathrm{OH}$ 基モル比）が 1.0 未満では過剩と なったポリオール成分が，1.0 以上では過剩となったイソ シアネート成分が未反応物として残留することが予想され る.R 值がシーリング材の性能に影響を及ぼすことから ${ }^{9)}$, $\mathrm{R}$ 值の最適範囲を見出す必要が生じる.

本報では，脂肪族ポリイソシアネート（C-2612）とポリ オール混合物（N-4188）の配合比を変化させることでR 值 を変え, その際のウレタンポリマーの各種特性に及ぼす影 響を検討した。また，添加剤を配合したウレタン・シーリ ング材の R 值による特性変化から最適 $\mathrm{R}$ 值範囲を決定した. さらには, 工業的な 2 液配合における最適組成比の保持と 生産工程における R 值の管理法を見出したので報告する.

\section{2. 実験}

\section{1 サンプル調製}

ポリイソシナネートとして, ヘキサメチレンジイシシア 
ネート (HDI) と 1,3-ブチレングリコール（1,3-BG）から なる日本ポリウレタン製C-2612（CAS No.359013-50-6, HDI-(1,3-BG)-HDI）アダクト体を使用した。C-2612は 2 官 能プレポリマーであり分子量は $430 \mathrm{~g} / \mathrm{mol}$, イソシアネー ト価（NCO価）は $4.17 \mathrm{mmol} / \mathrm{g}$ であった.

ポリオールとして，日本ポリウレタン製N-4188を使用 した。 N-4188には，保土ヶ谷化学製ポリエーテルポリオ ール PTG-1000SN（CAS No.2519013-50-6）およびクラレ 製ポリエステルポリオール P-1010NF (CAS No.39751-34-3) が混合されている. PTG-1000SNはポリテトラメチレンエ ーテルグリコール (PTMG) であり，P-1010NFはアジピ ン酸（AA）と3-メチル-1,5-ペンタンジオール（MPD）の 重縮合物である。これら 2 官能プレポリマーの分子量は $1000 \mathrm{~g} / \mathrm{mol}$ である。また，N-4188にはクラレ製 3 官能ポ リエステルポリオール F-510（CAS No.122310-07-0）も架 橋剤（鎖延長剤）として混合されている。F-510はAA， $\mathrm{MPD}$ ，トリメチロールプロパン（TMP）からなる重縮合 物であり，分子量は $500 \mathrm{~g} / \mathrm{mol}$ である．用いたポリオール の水酸基価（OH価）は，それぞれ，PTG-1000SNが 1.92 $\mathrm{mmol} / \mathrm{g}, \mathrm{P}-1010 \mathrm{NF}$ が $2.00 \mathrm{mmol} / \mathrm{g}, \mathrm{F}-510$ が 6.23 $\mathrm{mmol} / \mathrm{g}$ であった。 N-4188中における PTG-1000SN, P1010NF およびF-510の配合比は，それぞれ，66.7 wt\%， 22.2 wt\%および11.1 wt\%であった。したがって， N-4188 の $\mathrm{OH}$ 価は $2.41 \mathrm{mmol} / \mathrm{g}$ となる.

脂肪族ポリイソシアネートC-2612 とポリオール混合物 $\mathrm{N}-4188$ の配合比（wt\%）を変化させ， R 值が異なるウレタ ンポリマーおよびウレタン・シーリング材を作製した。ウ レタンポリマーの成形に用いる反応触媒には共同薬品製 ジ-n-オクチル錫マレートポリマーの KS-1010A-1（CAS No.30173-13-8）を，酸化防止剂としてはBASF 製ヒンダー ドフェノール系のIRGANOX1010を使用した。

ウレタン・シーリング材の調製には, 充填剤として浅田 タルク製のタルク SW-A，着色剂としてDu Pont製の酸化 チタンTi-PURE R902を用いた。また，滑剤には日本油脂 製エルカ酸アミド（ALFLOW P-10）およびオレイン酸アミ
ド（ALFLOW E-10）からなる脂肪族アミドならびに信越 化学製のシリコーンオイル（KF-96-1000CSおよびKF-96300CS）の混合物を配合した。発泡剂にはAKZO NOBEL 製熱膨張性中空粒子EXPANCEL DU092-120を用いた。

Table 1 は R 值が 1.06 のきのウレタンポリマー (TOYO-UR）およびウレタン・シーリング材（UR1080） の典型的配合である。ポリオール混合物 N-4188に上記添 加剤を配合したコンパウンドを予め調製しておき，ポリイ ソシアネート成分 C-2612 との混合比を変化させて各種 R 值のウレタン・シーリング材を作製した。評価用サンプル シートおよびキャップは，ポリオールとポリイソシアネー トの 2 液を所定の配合比で混合した後，所定の条件下で熱 硬化させることで作製した。

\section{2 力学特性}

動的粘弾性測定はオリエンテック社製レオバイブロン DDV-01/25FPを用い, 周波数 $11 \mathrm{~Hz}$, 昇温速度 $2{ }^{\circ} \mathrm{C} / \mathrm{min}$ にて， - $100{ }^{\circ} \mathrm{C}$ から $200{ }^{\circ} \mathrm{C}$ まで測定した。長さ $40 \mathrm{~mm}$, 幅 $5 \mathrm{~mm}$, 厚さ $2 \mathrm{~mm}$ の試料に振幅 $25 \mu \mathrm{m}$ の動的振動を印 加し測定した。圧縮永久ひずみ $(C S)$, JIS A 硬度 $\left(H_{\mathrm{A}}\right)$, 引張試験は，それぞれ，JIS K 7312の各測定法に従って実 施した. 引張試験では, 引張強度 $\left(T_{\mathrm{B}}\right)$, 破断伸び $\left(E_{\mathrm{B}}\right)$, $100 \%$ 引張応力 $\left(M_{100}\right)$ を求めた. $C S$ は $25 \%$ の圧縮ひずみ を負荷し， $70{ }^{\circ} \mathrm{C} ， 22$ 時間後の值とした.

\section{3 蒸発残渣測定}

未反応物の溶出試験は厚さ約 $600 \mu \mathrm{m}$ のポリウレタン・ シートを $95 \%$ エノール水に $66{ }^{\circ} \mathrm{C} て ゙ 2$ 時間浸漬し，その 後の蒸発残留物量に基づき評価した。単位面積当たりの溶 媒量は $3.1 \mathrm{ml} / \mathrm{cm}^{2}\left(20 \mathrm{ml} / \mathrm{inch}^{2}\right)$ とした。

\section{4 キャップ性能評価}

口径 $\phi 53 \mathrm{~mm}$ のツイストオフキャップを作製後，ガラ ス瓶に $80{ }^{\circ} \mathrm{C}$ 温水を充填し, 所定条件で巻き締めてサンプ ルを作製した，作製サンプルを用い，開栓トルク，横圧強 度，食込み值を測定した。横圧強度は，テンシロンを用い てキャップの両側から荷重を負荷した際に，シール部外縁 からブルーダイの吸い込みが認められた荷重とした。食込

Table 1 Typical compositions for polyurethane (TOYO-UR) and urethane sealing gasket (UR1080).

\begin{tabular}{|c|c|c|c|c|}
\hline Dev & d - & Material type & Product name & Weight ratio phr \\
\hline \multirow{13}{*}{$\begin{array}{l}\text { Sealing gasket: } \\
\text { UR1080 }\end{array}$} & \multirow{6}{*}{$\begin{array}{l}\text { Base polymer: } \\
\text { TOYO-UR }\end{array}$} & Polyisocyanate & C-2612 & 38.0 \\
\hline & & \multirow{3}{*}{$\begin{array}{l}\text { Polyols: } \\
\text { N-4188 }\end{array}$} & PTG-1000SN & 41.3 \\
\hline & & & P-1010NF & 13.8 \\
\hline & & & F-510 & 6.9 \\
\hline & & Catalyst & KS-1010A-1 & 0.02 \\
\hline & & Antioxidant & IRGANOX1010 & 0.19 \\
\hline & & Filler & SW-A & 15.0 \\
\hline & & Colorant & Ti-PURE R902 & 2.0 \\
\hline & & \multirow{4}{*}{ Lubricants } & ALFLOW P-10 & 4.0 \\
\hline & & & ALFLOW E-10 & 4.0 \\
\hline & & & KF-96-1000CS & 1.0 \\
\hline & & & KF-96-300CS & 1.0 \\
\hline & & Blowing agent & DU092-120 & $0.45-0.70$ \\
\hline
\end{tabular}


み值は，密封後一定条件で経時保存した後に開栓し，変形 回復させた後のシーリング材の平均厚みと初期厚みの差と 定義した。

\section{3. 結 果と 考 察}

\section{1 力学特性}

Figure 1 はウレタンポリマーのR值を 0.95 から 1.15 まで変 化させた場合の貯蔵弾性率 $\left(E^{\prime}\right)$ ，損失弾性率 $\left(E^{\prime \prime}\right)$ および 損失正接（ $\tan \delta ）$ の温度依存性である。また，Figure 2 は $E^{\prime}$ の温度依存性を R值の関数として実数で表示している． R が 1.00 から 1.15 の場合，すなわち， NCO 基がリッチな場 合， - 10 から $140{ }^{\circ} \mathrm{C}$ の広範な温度域でゴム状平坦部（プラ トー）が観測された。この温度域で $E^{\prime} は$ 温度上昇とともに 増加しており，エントロピー弾性が発現していることが明 らかである。また，この温度域において，一定温度での $E^{\prime}$ および $E^{\prime \prime}$ 值はR $\mathrm{R}$ 值とともに，それぞれ，大きくおよび小さ くなった。これは $\mathrm{R}$ 值の増大とともに架橋密度が増大する こと, すなわち, 架橋点間分子量が低下することを示唆し ている。，一方， $\mathrm{OH}$ 基リッチな $\mathrm{R}=0.95$ の場合，上述の温度 域において $E^{\prime}$ は温度上昇とともに低下した。この結果は未 反応ポリオールが $E^{\prime}$ を低下させ， $E^{\prime \prime}$ を上昇させることを示

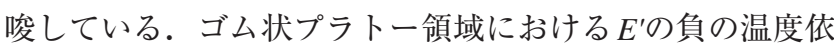
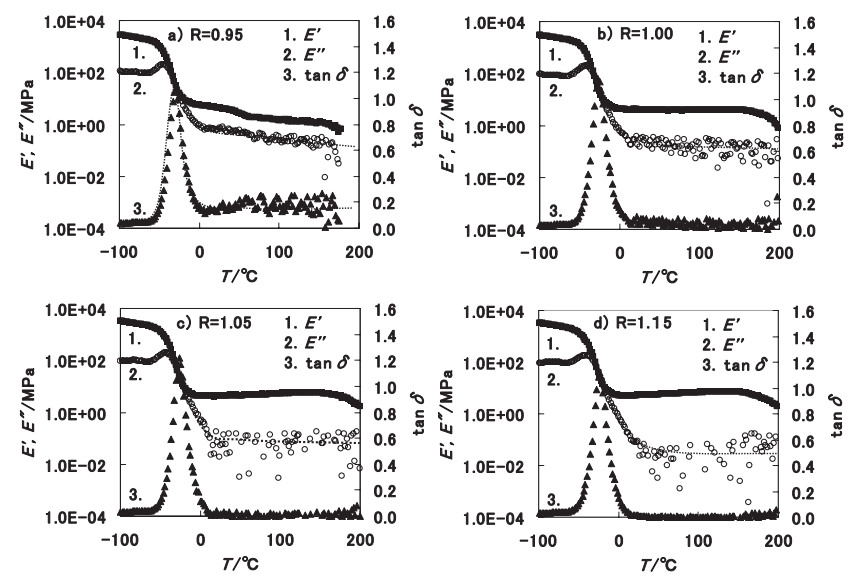

Figure 1 Dynamic viscoelastic properties of polyurethane with various $\mathrm{R}$-values; (a) $\mathrm{R}=0.95$, (b) $\mathrm{R}=1.00$ ，（c） $\mathrm{R}=$ 1.05, (d) $\mathrm{R}=1.15$

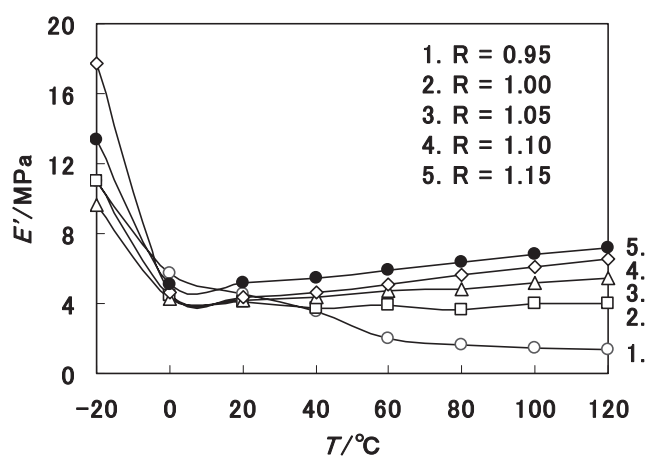

Figure 2 Temperature dependence of storage modulus $\left(E^{\prime}\right)$ of polyurethane with various $R$-values.
存性も未反応ポリオールによる可塑化効果によって網目を 構成するセグメントの運動性が増大したと考えれば説明で きる. $150{ }^{\circ} \mathrm{C}$ のうな高温においても $E^{\prime}$ の急激な低下，す なわち，流動化は認められなかったことから，網目構造は 系全体で有効に形成されていると考えられる。

ゴム弾性理論から，ヤング率 $E$ は $3 \rho \mathrm{R} T / M_{c}\left(1-2 M_{c} / M_{n}\right)$ で与えられる。ここで， $\rho$ は密度， R はガス定数，Tは絶 対温度, $M_{c}$ は架橋点間分子量, $M_{n}$ は数平均分子量である ${ }^{10)}$. $M_{n}$ が十分に大きい場合，すなわち，架橋構造が導入され ている場合は $2 M_{c} / M_{n}$ は無視できる。したがって，Eは $M_{c}$ の逆数および $T$ に比例する。ここで， $E^{\prime} と E$ を等価である と仮定すれば， $\mathrm{R}$ 值が 1.00 以上でも理想ゴムが形成される といえる．換言すれば， $\mathrm{R}$ 值が 1.00 以上でもイソシアネー 卜は反応し, 網目の構成に寄与すると考えられる. 既報 ${ }^{8)}$ では，ポリマー設計から想定される $M_{\mathrm{c}}$ と $3 \rho \mathrm{R} T / E$ から求 められた $M_{\mathrm{c}}$ が一致することを報告し， $\mathrm{R}=1.06$ で $E=$ $3 \rho \mathrm{RT} / M_{c}$ が成立していることを示した。

Figure 3 はウレタンポリマーの R 值とCS および $H_{\mathrm{A}}$ の関 係である．CS はR 值 0.95 で40\%と大きかったが， R 值が 1.00 以上になると $5 \%$ 以下の值となった。この結果は， $\mathrm{R}$ 值が 1.00 以上の場合, 試料は荷重の開放とともに元の形状 に復元することを意味している， $H_{\mathrm{A}}$ においても同様の $\mathrm{R}$ 依存性が観測された。 $H_{\mathrm{A}}$ は $\mathrm{R}$ 值 0.95 で 80 と高く，1.00 以 上で 60 程度となった。 $H_{\mathrm{A}}$ は $\mathrm{R}$ 值 1.05 で最も小さく， $\mathrm{R}$ 值 の増加とともに大きくなった。

$\mathrm{R}=0.95$ で観測された硬度の顕著な上昇は，運動性が高 い未反応の PTMGが結晶化したことに起因する11,12).こ の值は前報 ${ }^{8)}$ で報告したエチレン・プロピレン・ラバー （EPR）の硬度程度である. $\mathrm{R}=1.00$ 以上のウレタンポリ マーにおいても PTMGの結晶化による硬度上昇が経時進 行する場合がある。本研究ではこれを防止するため, P1010NF，F-510にMPDを導入したメチル基ペンダントを 有するポリオールを，また，C-2612ではHDIのポリイソ シナネート・アダクト体にメチル基ペンダントを有する 1,3-BG を使用している。したがって， R 值 1.05 以上の硬度 上昇は架橋密度の上昇に由来すると考えられる。

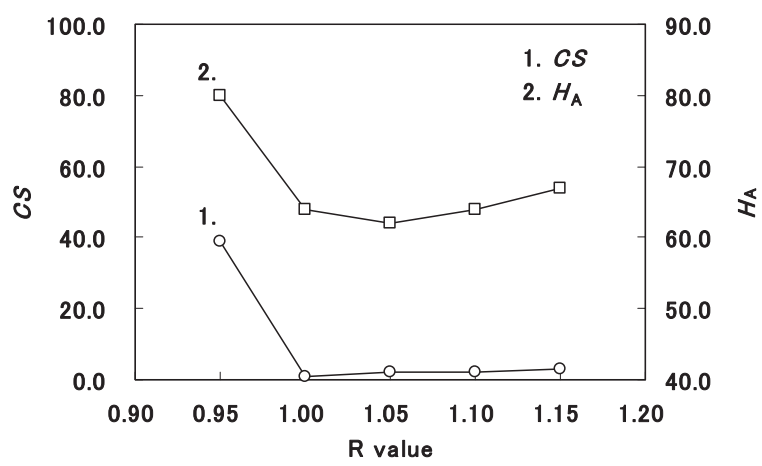

Figure 3 Compression set $(C S)$ and JIS A hardness $\left(H_{\mathrm{A}}\right)$ of polyurethane with various $\mathrm{R}$-values. 
Figure 4 は示差走査熱量（DSC）測定に基づき評価し た熱的挙動の R 值依存性である。ここで用いた試料は添加 剤を配合したウレタン・シーリング材であり，C-2612 と $\mathrm{N}-4188$ コンパウンドの配合比を変更することで幅広く $\mathrm{R}$ 值を調整した。 $\mathrm{R}$ 值が小さい場合は結晶融解ピークが観測 された. $\mathrm{R}<0.97$ の場合，二つのピークが観測されており 低温側は過剰なPTMGの融解ピークである ${ }^{11)}$. 高温側は PTMGおよび／またはC-2612のウレタン化物の融解ピー クであると考えられる。原料の DSC 測定では，N-4188で $17{ }^{\circ} \mathrm{C}$ と $26{ }^{\circ} \mathrm{C}$ の 2 所に, C-2612では $35{ }^{\circ} \mathrm{C} に$ 融解ピーク

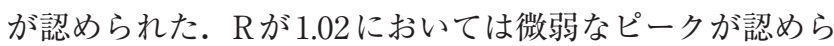
れたが，それより大きな $\mathrm{R} の$ 場合，架橋密度の増大によっ てPTMGの結晶化が阻害されることが明らかである。し たがって， $\mathrm{R}=1.05 て ゙$ 観測された最小の硬度は結晶化と架 橋密度の絶妙なバランスによって発現したと推察できる.

Figure 5 はウレタンポリマーの R 值と引張特性の関係で ある. $100 \%$ 引張応力 $M_{100}$ は R 0.95 から 1.15 の範囲で $\mathrm{R}$ 值と ともに単調に増大している. 一方, 引張強度 $T_{\mathrm{B}}$ は $\mathrm{R}=1.00$ で最大の $13.6 \mathrm{MPa}$ であり， $\mathrm{R}$ 值の増大とともに低下し, $\mathrm{R}>1.10$ では3.5 MPaで一定となった。破断伸び $E_{\mathrm{B}}$ は $\mathrm{R}$ 值 が小さいほど大きく， $\mathrm{R}=0.95$ で $850 \%$ あったた， $E_{\mathrm{B}}$ は R 值

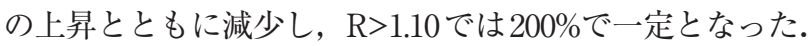

$M_{100}$ がR值とともに増大する傾向はゴム状プラトーの $E^{\prime}$ の結果と一致している。 $T_{\mathrm{B}}$ および $E_{\mathrm{B}}$ に関しては，R值の 増大とともに減少した後，一定になることから，架橋密度 がある值になると $T_{\mathrm{B}}$ および $E_{\mathrm{B}}$ に影響を及ぼさなくなるこ

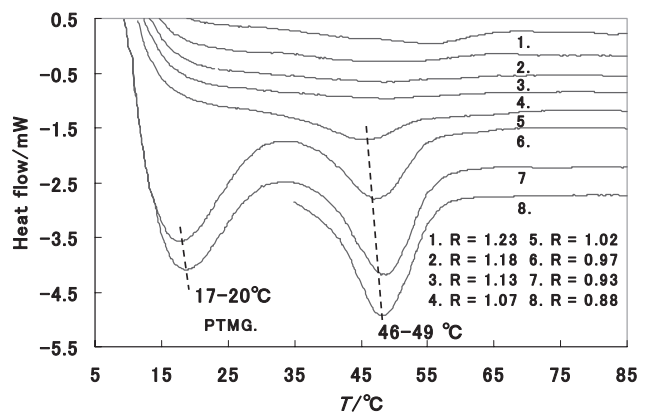

Figure 4 DSC charts for urethane sealing materials with various R-values.

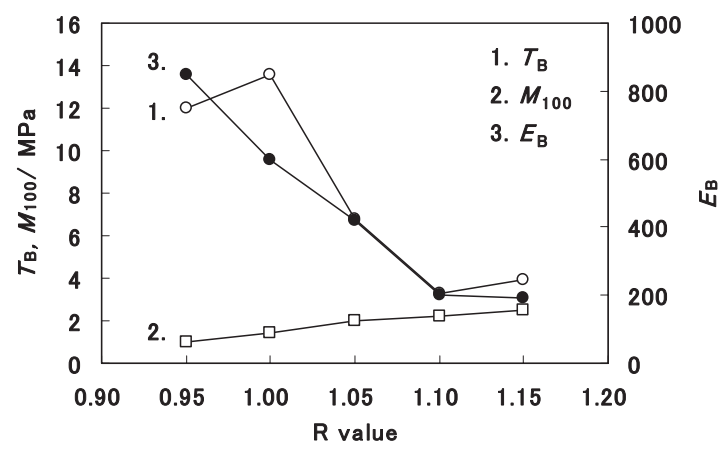

Figure 5 Tensile properties of polyurethane with various R-values.
とを示唆している.

ここまでを要約すると， $\mathrm{R}<0.95$ では $E^{\prime} の$ 温度依存性が 負の傾きを示すことから，理想とするシーリング材用基材 ポリマーとしては好ましくない。圧縮永久ひずみ CSにお いても， $\mathrm{R}<1.00$ では，急激な増大が観測された。硬度に おいても $\mathrm{R}<0.95$ で $\mathrm{EPR}$ 並の硬度となり好ましくない. 引張挙動に関しては， 1.00 以上の高 $\mathrm{R}$ 值で $T_{\mathrm{B}}$ と $E_{\mathrm{B}}$ の低下 が認められた. PVCライナー (発泡比重 $0.8 \mathrm{~g} / \mathrm{cm}^{3}$ ) の $T_{\mathrm{B}}$, $E_{\mathrm{B}}, M_{100}$ がそれぞれ5.0 MPa，200\%，3.3 MPaであったこ とから, $\mathrm{R}>1.10$ では $T_{\mathrm{B}}$ が劣っており, キャップ性能評価 による影響確認を要する。 $E_{\mathrm{B}}$ については問題ないレベル であった。 $M_{100}$ はR 值全域において $1 \sim 3 \mathrm{MPa}$ であり，柔 軟性の観点からシーリング材として適切である. 引裂き強 度（ $T_{\mathrm{R}} ）$ についても 20 から $25 \mathrm{~N} / \mathrm{mm}$ の優れた值であった (前記PVCライナーでは $21 \mathrm{~N} / \mathrm{mm}$ )。以上のことから, 一 部確認事項を残すもののウレタンポリマーの力学特性よ り， $\mathrm{R}$ 值が 1.00 から 1.15 の範囲が最適であると結論できる.

\section{2 溶出性}

Figure 6はウレタンポリマーのR值と $95 \%$ エタール水 による溶出物の蒸発残渣の関係である．溶出量は $\mathrm{R}=0.95$ で多く, $\mathrm{R}=1.00$ で急激に減少した後, $\mathrm{R}$ 值の増加ととも に減少した。このことから $\mathrm{R}$ 值 1.00 未満の $\mathrm{OH}$ が過剰な領 域では， $\mathrm{NCO}$ 基と $\mathrm{OH}$ 基のウレタン反応は完結せず，残 存した未反応ポリオールが抽出されたと考えられる. 化学 量論的には $\mathrm{R}=1.00$ でウレタン反応は完結するが，実際に は，反応率は $100 \%$ には至らない。このため， $\mathrm{R}=1.00$ に おいても有限の溶出量が観測される。 R值が増大すれば架 橋密度が上昇するため網目の膨潤が抑制され，その結果， 未反応物の溶出が物理的に減少する. シーリング材用基材 ウレタンポリマーとしては，溶出量が小さいほうが衛生的 に好ましく， R 值が 1.00 以上であることが推奨される。

\section{3 引張特性およびキャップ性能}

ウレタンポリマーと同様に，添加剤を配合したウレタ ン・シーリング材の R 值を 0.88 から 1.23 の範囲で変化させ た場合の引張特性, キャップ特性值を調査した. ウレタン ポリマーの比重 $1.08 \mathrm{~g} / \mathrm{cm}^{3}$ に対し, このときの発泡比重は

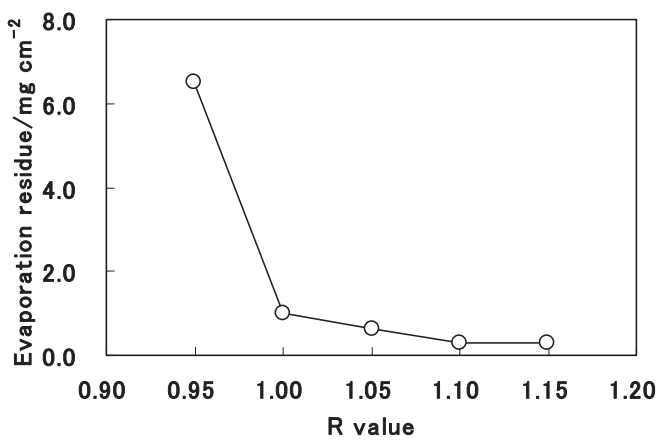

Figure 6 Evaporation residues of polyurethane with various R-values. 
$0.80 \pm 0.07 \mathrm{~g} / \mathrm{cm}^{3}$ の範囲であった. Figure 7 (a) はR R 值 に対し，シーリング材の食込み值（Impression value）を 左軸に，引張強度 $T_{\mathrm{B}}$ を右軸にプロットした。食込み值は シーリング材の圧縮永久ひずみ $C S$ と対応する特性であり, クリープ変形が大きいほど大きい. 食达み值が小さいシー リング材は開栓後に変形回復するため，密封下の長期経時 においてもシーリング材と瓶口との間の密封応力は保持さ れ，良好な密封性能を示すことになる，Rが 1.00 以上の場 合，食达み值が小さかったことからこの範囲の $\mathrm{R}$ 值が好ま しい. 一方， $T_{\mathrm{B}}$ は R が 0.97 から 1.02 の範囲で最大值 4.4 $\mathrm{MPa}$ を示し, R值の増加にともなって減少した。

添加剤有無（Figure 7 （a）とFigure 5）における $T_{\mathrm{B}}$ の 比較から，添加剂を配合したシーリング材の $T_{\mathrm{B}}$ は全体的 に低下することがわかる。しかしながら， R 值が大きくな ると，ウレタンポリマーとシーリング材の $T_{\mathrm{B}}$ の差は小さ くなる。シーリング材の $E_{\mathrm{B}}$ は表示していないが，低 $\mathrm{R}$ 側 では添加剂効果のため，特に熱膨張性粒子がマトリックス の伸びに追従せず $E_{\mathrm{B}}$ は大きく低下し，その結果として低 $\mathrm{R}$ 側の $T_{\mathrm{B}}$ が大きく低下したものと考えられる。架橋密度 が大きい高 $\mathrm{R}$ 側では添加剤効果，特に熱膨張性中空粒子の 変形によって $E_{\mathrm{B}}$ が増大し， $T_{\mathrm{B}}$ の低下が抑制されると推定 される， Rが 1.00 から 1.15 の範囲におけるシーリング材の $T_{\mathrm{B}}$ は4.4から $3.1 \mathrm{MPa}$ の值であった。この $T_{\mathrm{B}}$ 範囲において キャップ性能評価に不都合が現れないことを確認した。

Figure 7 (b) はR 值と横圧強度 (Lateral force), 開栓卜 ルク（Opening torque）の関係である。横圧強度はR值の 増大とともに上昇し，1.07付近から一定になった。一方， 開栓トルクは R 值の増大とともに減少し，0.97以上でほぼ 一定となり，良好な開栓トルクを示した。開栓トルクと食 込み值は極めて似た曲線を描いており，低 $\mathrm{R}$ 值側での大き な食込み值がシール部の接触面積を増大させ，開栓卜ルク の増大を招くと考えられる. また, 横圧強度も食込み值と の相関性が高く，食込み值が小さくなるほど横圧強度は増 大する. $\mathrm{R}=0.97$ の高い食达み值に対し，開栓トルクが低 下する理由は密封応力の低下に求められる。，一方， $\mathrm{R}=1.02$ の低い食込み值に対し，横圧強度が最大值まで上昇しない 理由はポリウレタン（マトリックス）の架橋度の不足によ る弾性力の不足に求められる。これはFigure 1，2の動的粘
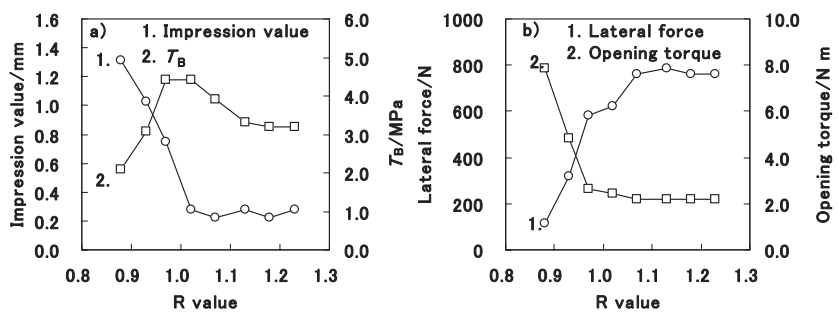

Figure 7 Characteristics of urethane sealing gaskets with various R-values; (a) impression value and $T_{\mathrm{B}}$, and (b) lateral force and opening torque.
弾性, Figure 5 の $M_{100}$ から予見される.

以上より,引張特性およびキャップ性能評価においても, ウレタン・シーリング材の好適な $\mathrm{R}$ 值範囲は 1.00 から 1.15 であることが支持された。特にNCOが若干リッチな 1.05 から 1.07 の $\mathrm{R}$ 值範囲が各種性能バランスに優れていた。

$\mathrm{R}>1.15$ の領域では，過剩な NCO成分が長時間残存す るため表面にタックが残り生産性が劣る。また， $\mathrm{R}=1.23$ では，JIS A 硬度が38（焼付 1 日後）から50（4日後）に 変化した。これはFigure 4 で $\mathrm{R}=1.23$ にブロードな吸熱ピ ークが認められることと一致する。過剩 $\mathrm{NCO}$ 基の反応に ついては以下の赤外吸収スペクトルにおいて論じるが， $\mathrm{R}=1.15$ では過剩 NCOの消失に 3 日を要した。

\section{4 赤外吸収スペクトル}

ウレタンポリマーの力学特性および溶出性（衛生性・安 全性）の観点から $\mathrm{R}=1.00$ から 1.15 が好適範囲であること が明らかとなった。また， $\mathrm{R}$ 值が大きくなるほど，架橋密 度の上昇，すなわち，架橋点間分子量の減少が予測され， ポリマー中の網目がより緻密化するものと推定される.

Figure 8 は $\mathrm{R}=1.15$ のウレタンポリマーの反応後 4 時間 （上）と 3 日後（下）の赤外吸収（IR）スペクトルである. 反応 4 時間後のスペクトルには $2270 \mathrm{~cm}^{-1}$ 付近に $\mathrm{NCO}$ 基に 由来するピーク 13) が明確に観測されている. 一方，3日後 には $2270 \mathrm{~cm}^{-1}$ のピークが消失していた。同様に $\mathrm{R}=1.00$, 1.05，1.10の3 種のウレタンポリマーの焼付直後，2時間後， 4 時間後， 3 日後における $\mathrm{NCO}$ 基由来の吸収バンドを追跡 した（スペクトルは示していない）。 $\mathrm{R}=1.00$ の場合， $\mathrm{NCO}$

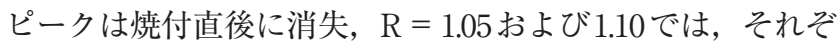
れ， 2 および 4 時間後に消失した。 $\mathrm{R}=1.00$ 以上の場合の残 存未反応 $\mathrm{NCO}$ の一部は空気中の水分と反応し，アミノ基と 二酸化炭素を生成する．生成したアミノ基は残存 NCOの一 部と反応してウレア結合を生成し ${ }^{14)}$, 架橋密度が上昇する. この傾向は R值の増大とともに顕著となる.

Figure 9 は脂肪族ポリイソシアネート (C-2612)，N4188 に添加剤を配合したポリオール，両者の混合物のIR

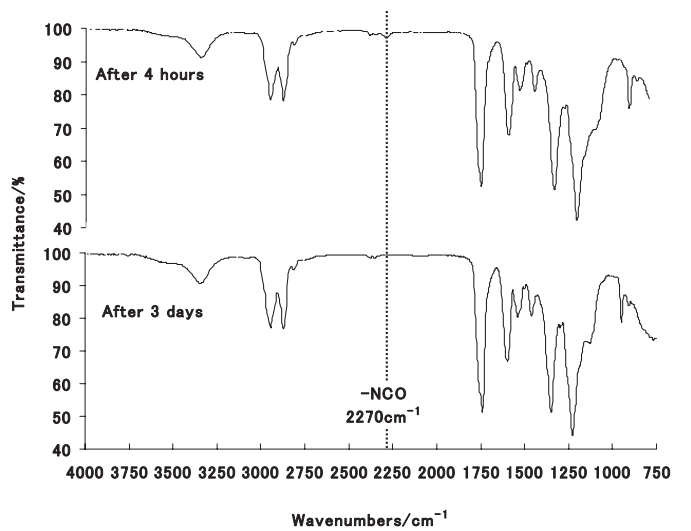

Figure 8 IR spectra for urethane with R-value after thermal curing. 


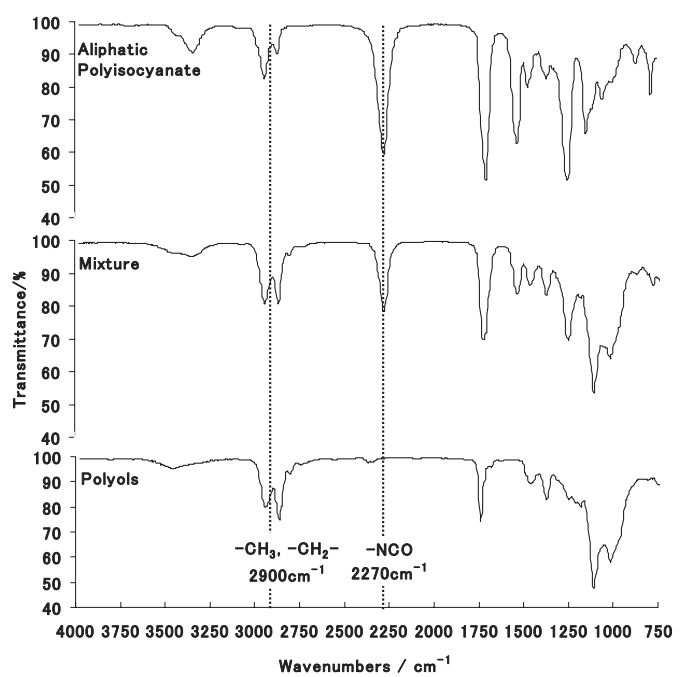

Figure 9 IR spectra of aliphatic diisocyanate, polyol compound and urethane sealing compound with additives.

スペクトルである．C-2612 と混合物のIR スペクトルには $2270 \mathrm{~cm}^{-1}$ にCO基のピークが認められ，ポリオールに は $2270 \mathrm{~cm}^{-1}$ には何れのピークも認められなかった。一 方, $2900 \mathrm{~cm}^{-1}$ にはC-2612, ポリオール，それらの混合 物の 3 者にメチル基，メチレン基のアルキル基ピークが認 められた。開発した脂肪族ウレタン・シーリング材におい ては， R 值を 1.00 から 1.15 の範囲に制御して 2 液の混合物 をインラインで自動調製し，金属キャップにライニングし て焼付硬化させる．2液の混合物において，IRの 2900 $\mathrm{cm}^{-1}$ のアルキル基ピークを混合比により変化しない基準 ピークと見做し，（2270 $\mathrm{cm}^{-1} \mathrm{NCO}$ ピーク面積） / (2900 $\mathrm{cm}^{-1}$ アルキル基ピーク面積）を $\mathrm{R}$ 值に対しプロットした 結果を Figure 10 に示す。 $\mathrm{R}=0.88$ から 1.29 の範囲におい て一次の相関が見出された。これにより簡便なIR測定に よって自動調製した 2 液混合液の $\mathrm{R}$ 值を短時間で決定する ことが可能となった。

\section{4. ま と め}

$\mathrm{R}$ 值（ $\mathrm{NCO}$ 基/ $\mathrm{OH}$ 基モル比）を変化させた脂肪族ポリ イソシアネート（C-2612）とポリオール（N-4188：PTG1000SN, P-1010NF，F-510）からなるウレタンポリマー の力学特性, 溶出挙動を調査し, 最適 $\mathrm{R}$ 值範囲を $1.00 \leqq$ $\mathrm{R} \leqq 1.15$ と決定した。 $\mathrm{NCO}$ 基過剩な $\mathrm{R}$ 值範囲において動 的粘弾性測定では広範な温度域にゴム状プラトーが現れ， 低いJIS A 硬度，低い圧縮永久ひずみを示し，シーリング 材用基材ポリマーとして理想的な力学特性が得られた。ま た， $\mathrm{R}=1.00$ 以上で溶出性が著しく改善された。

添加剂を配合したウレタン・シーリング材においても引 張特性およびキャップ性能評価から最適 $\mathrm{R}$ 值範囲が $1.00 \leqq$ $\mathrm{R} \leqq 1.15$ であることが確認できた。この $\mathrm{R}$ 值範囲において 密封性と開栓性に優れたシーリング材が得られた。

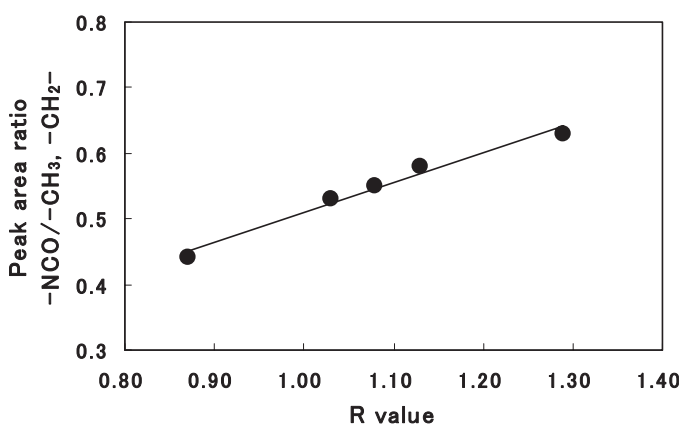

Figure 10 Primary correlation between $\mathrm{R}$-value and peak area ratio of $\mathrm{NCO} /$ alkyl $\left(-\mathrm{CH}_{2-}\right.$ and $\left.-\mathrm{CH}_{3}\right)$.

IRスペクトルからウレタン反応後の過剩な $\mathrm{NCO}$ 基は消 失することが確認された. ウレア結合が形成されるものと 推測され, これにより, 架橋構造が強化され, ウレタン諸 特性を向上させている。また，IR測定により R 值 vs. (2270 cm $\mathrm{cm}^{-1}$ の NCO 基ピーク面積) / (2900 $\mathrm{cm}^{-1}$ のアル キル基ピーク面積）プロットから未知試料の $\mathrm{R}$ 值を決定で きる。これにより諸特性のバランスが最良の $\mathrm{R}$ 值（1.05〜 1.07）を狙ってキャップ製造を行うことが可能となった.

\section{References}

1 ) Hammarling, L.; Gustavsson, H.; Svensson, K.; Karlsson, S.; Oskarsson, A.: Food Add. Contam., 15 (2), 203 (1998)

2 ) Fantoni, L.; Simoneau, C.: Food Add. Contam., 20 (11), 1087 (2003)

3 ) Frankhauser-Noti, A.; Biedermann-Bern, S.; Grob, K: Eur. Food Res. Tech., 223, 447 (2006)

4 ) Kanno, S.; Kawamura, Y.; Mutsuga, M.; Tanamoto, K.: Shokuhin Eiseigaku Zasshi, 47 (4), 196 (2006)

5 ) Takemura, Y.: Kogyo Zairyo, 46 (3), 28 (1998)

6 ) Moriga, T.; Yokota, H.; Tsuchida, T.; Yano, N.: US Patent 6872796 (2005)

7 ) Moriga, T.; Aoyama, N.; Tsuchiya, H.; Komaki, T.: US Patent 6878449 (2005)

8 ) Moriga, T.; Aoyama, N.; Tanaka, K.: Polym. J., 47 (5), 400 (2015)

9 ) Mohapatra, S.; Mohanty, N.; Satapathy, J.; Guru, B., Pal, N.: J. Chem. Pharm. Res., 6 (4), 1126 (2014)

10) Krevelen, D.W.V.; Nijenhuis, K.T.: "Properties of Polymers (4th completely revised ed.)", Elsevier, Amsterdam, Chapter 13 (2009)

11) Shirasaka, H.; Yamashita, M.; Inagaki, T.; Inoue, S.; Okamoto H.: Nippon Goти Kyokaishi, 72, 123 (1999)

12) Takahashi, H.; Shibayama, M.; Hashimoto, M.; Nomura, S.: Macromolecules, 28, 5547 (1995)

13) Furukawa, M.: Nippon Gomи Kyokaishi, 84, 124 (2011)

14) Furukawa, M.: Setchaku no Gijutsushi, 31 (1), 1 (2011)

\section{日本語表記参考文献}

4 ）菅野慎二, 河村葉子, 六鹿元雄, 棚元憲一：食品衛生学雑誌, 47 (4), 196 (2006)

5 ) 竹村泰彦: 工業材料, 46 (3), 28 (1998)

11）白坂仁，山下恵美，稲垣忠弘，井上眞一，岡本弘：日本ゴム協 会誌，72，123（1999）

13）古川睦久：日本ゴム協会誌，84，124（2011）

14）古川睦久：接着の技術誌，31（1），1（2011） 